\title{
EUROPEAN UNION SUPPORT AND TRANSITIONAL JUSTICE PROCESSES IN KOSOVO
}

\author{
Remzije Istrefi \\ Professor Assistant \\ Faculty of Law, University of Prishtina \\ Prishtina/Kosovo \\ remzie.istrefi@uni-p.edu
}

\begin{abstract}
The legacy of systematic human rights violations committed during 1999 violent conflict and the previous repressive rule still impact the everyday life of Kosovo citizens. That is why transitional justice processes are a necessary component in Kosovo's state building efforts. With the end of the 1999 conflict, Kosovo has been administered by the United Nations Mission in Kosovo (UNMIK) and also supported by European Union (EU) presences: the EU Special Representative in Kosovo, and European Union Rule of Law Mission known as EULEX. In the course of implementation of their mandates transitional justice processes were not a priority for UNMIK and EU presences. With the signing of the Stabilization and Association Agreement (SAA) the EU made transitional justice part of the Kosovo accession demands. In December 2015, the Government of Kosovo approved its National Action Plan for the Implementation of the Stabilization and Association Agreement (NAPISAA). The General Principles of the SAA, included within the NAPISAA oblige Kosovo Government to approve a National Transitional Justice Strategy. This paper analyses EU peace and institutionbuilding support and their impact in transitional justice processes in Kosovo. Through analysing the mandate and actions on the ground it draws conclusions if $\mathrm{EU}$ is an active participant in transitional justice process in Kosovo or transitional justice policies are promoted by EU only as part of its enlargement
\end{abstract}


strategy. Finally, the paper gives recommendations as a basis for future elaboration of an EU approach to transitional justice.

\section{Keywords}

EU, EULEX, Human rights, Transitional Justice, UNMIK.

\section{INTRODUCTION}

Dealing with the legacy of mass atrocities in a period of change after violent conflict and/or regime change is a challenging and complex task. Transitional justice has emerged as a possible response to the difficult dilemmas that the transformations generate. It is a way to articulate the different processes considered necessary to help a society move from a period of repression and/or conflict to one in which human rights, democracy and the rule of law can prevail (Institute for Democracy and Conflict Resolution 2011, 10). According to the most commonly used definition first published in the United Nations (UN) SecretaryGeneral's report on the rule of law and transitional justice in conflict and postconflict societies in 2004 transitional justice can be described as "the full range of processes and mechanisms associated with a society's attempts to come to terms with a legacy of largescale past abuses, in order to ensure accountability, serve justice and achieve reconciliation" (Report of the UN Secretary General 2004, 2). These may "include both judicial and non-judicial mechanisms, with differing levels of international involvement (or none at all) and individual prosecutions, reparations, truth-seeking, institutional reform, vetting and dismissals, or a combination thereof" (Report of the UN Secretary General 2004, 4). This definition incorporates: the right to know, right to justice, right to non-recurrence and right to reparation, the four principles which are widely acknowledged to constitute the core elements of transitional justice (Sisson 2001, 2). Experience has shown that the most successful transitional justice processes are those initiated by the local populations and which were characterized by the local ownership and allinclusive consultation processes. The consultation and transparent activities of the Truth and Reconciliation Commission in post apartheid South Africa in 1999s 
(Tietel 2003), the overall engagement of the victims and their families in discovering the whereabouts of the disappeared persons in Argentina by the Argentine National Commission on the Disappeared (Hayner 1994, Hayner 2001), and inclusion of women and youth in consultation and reconciliation process in Northern Ireland (Ward 2005) are among many models to be considered by the societies undergoing transitional justice processes. In the past decades, the international and regional organizations and their missions play an influential and catalytic role in facilitating justice and reconciling divided societies through the post conflict peace building efforts. International organizations not only provide an intermediary role between the former enemies, but have become an effective participant in designing and undertaking activities that form part of the transitional justice mechanism in some cases aiming reconciliation among them. The UN SG Kofi Annan, acknowledged that there had been an increased focus by the UN on questions of justice, transitional justice, and the rule of law in conflict and post-conflict societies (UN SecretaryGeneral 2004, 4). He noted that direct UN involvement in post-conflict societies has been characterized by the importation of transitional justice apparatus, for example, in Kosovo and Timor-Leste, where the UN has been directly involved in the administration of judiciaries, police, and prison services. The normative foundation for the work of the UN in advancing transitional justice is the Charter of the United Nations (UN Charter of the United Nations 1945), and the main pillars of the modern international legal system: international human rights law, international humanitarian law, international criminal law, and international refugee law. Various UN instruments guarantee the rights and duties related to: the right to justice ( UN GA International Covenant on Civil and Political Rights 1966, Article 2, UN GA Convention against Torture and Other Cruel, Inhuman Degrading Treatment or Punishment 1984, Articles 4, 5, 7 and 12, UN GA International Convention for the Protection of All Persons from Enforced Disappearance 2006, Articles 3, 6, 7 and 11); the right to truth (UN GA International Covenant on Civil and Political Rights 1966, Article 2, UN GA International Convention for the Protection of All Persons from Enforced Disappearance 2006, Article 24): the right to reparations (UN GA Universal Declaration of Human Rights 1948, Article 8, UN GA International Covenant on 
Civil and Political Rights 1966, Article 2, UN GA International Convention on the Elimination of All Forms of Racial Discrimination 1965, Article 6, UN GA Convention against Torture and Other Cruel, Inhuman, Degrading Treatment or Punishment 1984, Article 6, UN GA International Convention for the Protection of All Persons from Enforced Disappearance 2006, Article 24, the UN GA Convention on the Rights of the Child 1989, Article 39), and the guarantees of non-recurrence of violations (UN GA International Covenant on Civil and Political Rights 1966, Article 2, UN GA Convention against Torture and Other Cruel, Inhuman, Degrading Treatment or Punishment 1984, Article 2, UN GA International Convention for the Protection of All Persons from Enforced Disappearance 2006, Article 23). Additionally, transitional codes, guidelines, and rule of law policy tools have been devised. The Office of the UN High Commissioner for Human Rights (OHCHR) released in 2006 the Rule-of law Tools for Post conflict States (OHCHR, Rule-of law Tools for Post-conflict States 2006). The UN Secretary General provides in his Guidance Note the guiding principles and framework for a United Nations approach to transitional justice processes and mechanisms (United Nations Guidance Note of the SecretaryGeneral 2010).

Simultaneously, the European Union has increased its involvement in crisis management and through its peace- and institution building programmes has become one of the major contributors in post conflict territories. The Treaty on European Union, provides that the "The U nion's aim is to promote peace, its values and the wellbeing of its peoples" (EU Treaty Establishing the European Community 1957, Article 3.1). The EU is committed to promoting peace, to the protection of the EU's rights and to the strict observance and the development of international law (EU Treaty Establishing the European Community 1957, Article 3. paras. $1 \& 5)$.

The EU founding documents (Treaty of the European Union 1957, Treaty of Maastricht 1992) do not provide for specific definition (Davlis 2014) and reference on Transitional Justice. However, several articles provide for a framework to accommodate transitional justice initiatives. Article 177.2 of the Maastricht Treaty specifies that European policy in the area of development cooperation will contribute to the general objective of development and 
consolidation of democracy and the rule of law, as well as respect for human rights and fundamental liberties (European Union Treaty of Maastricht 1992, Article 177.2). Similarly, Article 11.1 of the European Union Treaty, which is the legal basis for Common Foreign and Security Policy (CFSP), establishes democracy, the rule of law and respect for human rights and fundamental liberties as priorities (European Union Treaty Establishing the European Community 1957, Article 11.1). Article 17.2 of the European Union Treaty provides for CFSP tasks and lists among others the "humanitarian and rescue tasks, peacekeeping tasks, and tasks of combat forces in crisis management, including peacemaking" (European Union Treaty Establishing the European Community 1957, Article 17.2). All these articles provide for the EUs undertakings towards states in crisis or in the territories that are undergoing the process of reestablishing peace after conflicts. At the level of EU legislation, explicit reference is made regarding the aspects of Transitional Justice in the Regulation no. 1889/2006 of the European Parliament and the Council, from December 20, 2006 which established a financial instrument for the promotion of democracy and human rights worldwide (Regulation no. 1889/2006 amended in 2014 (Regulation (EU) No 230/2014)). In Article 2, of the Regulation no. 1889/2006 through the financial instrument for the promotion of global democracy and human rights programme, the EU support seeks to: ii) "strengthen the rule of law, promoting the independence of the judiciary, encouraging and evaluating legal and institutional reforms, and promoting access to justice; iii) promote and strengthen the International Criminal Court, ad-hoc international criminal tribunals and the processes of transitional justice and truth and reconciliation mechanisms; iv) support reforms to achieve effective and transparent democratic accountability" The Instrument for Stability can support financially "international criminal tribunals and ad-hoc national tribunals, truth and reconciliation commissions, and mechanisms for the legal settlement of human rights claims and the assertion and adjudication of property rights, established in accordance with international human rights and rule of law standards." (Regulation (EU) No 230/2014 of the European Parliament and of the Council 2014: section (e)). It also provides "support for civilian measures related to the demobilisation and reintegration of former combatants into civil society, and where appropriate their repatriation, as well as measures to address the situation of child soldiers and female 
combatants" (Regulation (EU) No 230/2014 of the European Parliament and of the Council, 2014:section (g)). The inclusion of Demobilization, Disarmament and Reintegration (DDR) programmes is noteworthy, since is recognized as one of the necessary measures to be undertaken by societies in achieving non recurrence as a part of Transitional Justice itself.

The European Instrument for Democracy and Human Rights (EIDHR) is the main financial instrument that covers the period 2014-2020 with a total financial envelope of EUR 1,332,752,000. Under the new Regulation 235/2014 of the European Parliament and the Council, which replaces Regulation 1889/2006 (2007-2013), the EIDHR's budget has been increased with the aim to provide wider support for civil society and increase the EU's capacity to react promptly to human rights emergencies (European Commission, MEMO/13/1134. 8).

Transitional justice as an aspect to be carried out is found also in EU policy strands, in declarations, reports and consensus documents. Transitional Justice is envisaged in the Common Foreign \& Security Policy (CFSP), in the European Security and Defence Policy (ESDP) and the Cooperation Policy which all call for the promotion of democracy and human rights throughout the world (European Security Strategy, 2003) The main EU body for defining the CFSP's areas of action including the transitional justice actions is the EU Council. On 16 November 2015 the EU Council has adopted conclusions on the EU's support to transitional justice (EU's support to transitional justice - Council conclusions, 2015). With this document the EU Council reaffirmed the EU's intention to play an active and consistent role in its engagement with partner countries and international and regional organizations in support of transitional justice processes. The Council also adopted the EU's policy framework on support to transitional justice (The EU's Policy Framework on support to transitional justice, 2015). This document provides a framework for EU support to transitional justice mechanisms and processes and enhance the EU's ability to play a more active and consistent role, both in its engagement with partner countries and with international and regional organizations. It builds upon and complements the EU's existing strong policy in support of the International Criminal Court and takes account of the UN's framework and activities on transitional justice. 
Despite all the legal framework accommodating transitional justice aspects, the political commitments, policies and strategies to date the key question facing the international organizations through their peace building activities on the ground is how to deal with the painful legacy of past violence, while at the same time maintain the fragile peace and simultaneously implement their missions peace and state building mandates. The factual situation on the ground after the deployment of international presences in Kosovo exemplify this dichotomy in the international peace building efforts. In particular in the first years of international administration of Kosovo UNMIK (and KFOR) assumed almost all state functions over the territory. As a result of the conflict UNMIK was faced with destruction everywhere, including family homes, schools and hospitals. Roads were mined; bridges were destroyed; and radio and television were off the air. Mass killings and gross human rights violations by the Serbian military and paramilitary forces towards the Albanian populations; the unresolved issue of missing persons led to the interethnic conflict and incidents which at least twice in the life time of administration by UNMIK have risked the overall peace and security and with it have questioned the presence of the UNMIK and KFOR in Kosovo (Amnesty International 2000; Amnesty International 2004a Amnesty International 2004b, Human Rights Watch 2004; International Crises Group 2004). That is why through ought the exercise of their mandate UNMIK and latter EU presences directed their activities towards maintaining peace and security and institutional building and less dealt with the societal issues such are transitional justice process.

\section{TRANSITIONAL JUSTICE PROCESSES INTERNATIONAL ADMINISTRATION AND STEBUILDING PROCESSES IN KOSOVO}

There are several factors that should be taken into account when analysing transitional justice processes in Kosovo and the role of international actors. The NATO airstrikes over Serbia that lasted 78 days were concluded with the signing 
of the Military Technical Agreement (Military Technical Agreement 1999) that paved the way for instituting the civilian mission under the UN auspices known as UNMIK (UN SC Resolution 1244 1999). UNMIK's mandate was extensive and unprecedented both in scope and structural complexity. As authorized by the UNSC Resolution (UNSCR) 1244 of 10 June 1999, UNMIK's mandate included establishing an interim civilian administration including police, promoting the establishment of substantial autonomy and self-government in Kosovo, creating a democratic political atmosphere respectful of human rights, repatriating over one million refugees, supporting the reconstruction of infrastructure and the economic system, maintaining civil law and order, promoting human rights, and ensuring safe return of refugees and displaced persons to their homes. UNMIK was responsible for coordinating the reconstruction efforts of all international agencies operating in Kosovo. The OSCE was in charge of the Democratization and Institution Building (pillar III), and the EU was responsible for the Reconstruction and Economic Development pillar (pillar IV). Placed outside of the pillar structure, NATO's Kosovo Force (KFOR) mission was and continues to be responsible for providing a secure environment in Kosovo. The modalities for establishing conditions through which the past human rights abuses will not be repeated and ensuring accountability for past atrocities have been exemplified by the terms of peace settlements and political transitions which also paved the way for EU's extensive presence in Kosovo. These modalities relate to two major processes: development of a set of implementation standards for the Provisional Institutions for Self-Government (PISG), ${ }^{1}$ and the Final status processes. ${ }^{1}$ After

1 In December 2003, UNMIK published the Kosovo Standards Implementation Plan (Implementation Plan), which was subsequently endorsed by the Security Council. The Implementation Plan laid out the indicators that would establish "the basis for any review in mid-2005 to begin consideration of Kosovo's final status. The set of implementation standards for the PISG that involved establishment of a range of democratic governance principles i.e. a comprehensive legal framework covering political party operation and finances to be adopted and enforced...; all communities are proportionately represented at all levels of the PISG, in accordance with applicable legislation; the PISG and local municipal government decide and enact legislation in an 
the evaluation of the achievement of Standards before Status, in 2005, the process of defining the future status of Kosovo was initiated by the UN Security Council. The UN Secretary General authorized Martti Ahtisaari as the Special Envoy to develop the Comprehensive Proposal for the Kosovo Status Settlement (Comprehensive Proposal for the Kosovo Status Settlement 2007). The Status Settlement Proposal(Ahtisari plan) involved the internationally supervised independence of Kosovo by the international community and the EU. The EU specific role in Kosovo was reflected in the establishment of an International Civilian Office (ICO) and an EU mission in the rule of law area (EULEX) under the European Security and Defence Policy (ESDP). The Guiding principles for the envisaged international/EU presence in Kosovo was based on understanding that after the status settlement, the governance of Kosovo will be in the hands of its people and their elected authorities. Therefore, the activities to be undertaken by the international community and the EU imply a major shift from international governance towards Kosovo governance. In the Status settlement proposal (Ahtisari plan) the transitional justice has been deemed a constitutional

open, accountable and democratic manner...; PISG and Municipalities ensure the availability of basic public services such as health care, utilities and education, without discrimination to all communities in Kosovo...; all communities are fully and fairly represented amongst judges, prosecutors and in the Kosovo Police Service (KPS) and Kosovo Corrections Service (KCS)...; [and],there is effective action to eliminate violence against women and children, trafficking and other forms of exploitation, including preventative education and provision of legal and social services to victims". See generally Kosovo Standards Implementation Plan, Executive Summary, UNMIK, 31 March 2004.

${ }^{1}$ After more than six years of international administration by UNMIK in Kosovo, the international community agreed to open the issue of the future political status of Kosovo. In essence, the Contact Group, an informal grouping of six countries (USA, Russia, United Kingdom, Germany, France and Italy) in the second part of 2005, agreed to open the issue of the future political status of Kosovo. Subsequent to this, on 14 November 2005 the UN Secretary General appointed Marti Ahtisaari as the Special Envoy of the Secretary General of the United Nations for the process regarding Kosovo's future status (UNOSEK, 2007a). See generally: A comprehensive review of the situation in Kosovo, Eide Report (2005), S/2005/635. 
obligation. Article 2.5 of the Status settlement proposal (Ahtisari plan) states that "Kosovo Government shall fully promote reconciliation among communities and shall establish a comprehensive gender based sensitive approach for dealing with its past" (Comprehensive Proposal For the Kosovo Status Settlement 2007, Article 2.5). The main activities of $1 \mathrm{CO}$, in implementing the Status settlement proposal (Ahtisari plan), before disbanding in September 2012, were cooperation with the Government and the Kosovo Assembly in establishing an inter-ministerial working group on dealing with the past and also support in drafting the regulation on that working group (Rafaeli 2012). The ICO also intervened and proposed amendments to draft texts of the Laws on Witness Protection, War crimes prosecution, Political Prisoners, War Veterans, and Victim Compensation with particular interest in victims of sexual violence (Bernhardt and Ferizi 2011). ICO organized a series of consultation workshops with key officials from most ministries of the Kosovo government and CSOs as well (Muižnieks 2012), and it has publicly announced their approval of regional truth commission in the former Yugoslavia, known as RECOM initiative (De Leillo 2013).

With the end of supervised independence, the key document for undertaking the transitional justice processes is the Constitution of the Republic of Kosovo that came into force on the $15^{\text {th }}$ of June 2008 (Constitution of the Republic of Kosovo, 2008). Under its provisions on state responsibilities, it calls for "a spirit of tolerance, dialogue, and support reconciliation among communities" (Constitution of the Republic of Kosovo 2008, Article 58). Kosovo Constitution guarantees international human rights standards (Constitution of the Republic of Kosovo 2008, Chapter II), it secures a central role of international human rights agreements (Constitution of the Republic of Kosovo 2008, Article 22) and also contains extended protections for the rights of minority communities (Constitution of the Republic of Kosovo 2008, Chapter III). These constitutional values form the very essence of the constitutional influence on transitional justice processes in Kosovo. The human rights guarantees in the Constitution establish the societal and political conditions for national reconciliation, through guaranteeing societal and political processes to function and develop through elimination of previous patterns that have caused the conflict.The Constitution of Kosovo protects and promotes the rights and interests of communities and their 
members living in Kosovo. It states that "Kosovo is a multi-ethnic society consisting of Albanian and other Communities, governed democratically with full respect for the rule of law through its legislative, executive and judicial institutions, and guarantees full and effective equality for all its citizens" (Constitution of the Republic of Kosovo 2008, Article 3). The Constitution defines that "the official languages in Kosovo are Albanian and Serbian (Constitution of the Republic of Kosovo 2008, Article 5.1). Turkish, Bosnian and Roma languages can have the status of official languages at the municipal level or will be in official use at all levels as provided by law" (Constitution of the Republic of Kosovo 2008, Article 5.2). The Constitution also ensures equitable representation in public institutions, requires the representation of communities through several specific posts at the municipal level, enshrines the right of communities to "freely express, foster and develop their identity and community attributes" and establishes obligations of the state to ensure "full and effective equality among members of communities" (Constitution of the Republic of Kosovo 2008, Article 61). Finally, Chapter III also foresees the establishment of a Consultative Council for Communities, consisting of, amongst others, representatives of communities, with the mandate to afford communities the opportunity to comment at an early stage on legislative or policy initiatives, and to seek to have their views incorporated in relevant projects and programs.

The Constitution also protects the rights of communities in the legislative process. Out of an Assembly of 120 seats, it guarantees 20 seats for parties representing minority communities, with a specific number of seats assigned to the different communities (Constitution of the Republic of Kosovo, 2008: Article 64) Additionally, the Constitution requires the creation of the Assembly Committee on Rights and Interests of Communities and ensures that legislation covering certain issues will be considered legislation of vital interest, which requires a double majority for their adoption, amendment or repeal, both a majority of the entire Assembly and a majority of the deputies holding seats guaranteed for communities (Constitution of the Republic of Kosovo 2008, Article 81). Finally, any amendment of the Constitution itself requires a double two thirds majority, of both the entire Assembly and the deputies holding seats guaranteed for communities (Constitution of the Republic of Kosovo 2008, Article 144). 


\section{EUROPEAN UNION PEACEBUILDING EFFORTS AND TRANSITIONAL JUSTICE PROCESS IN KOSOVO}

With the declaration of Kosovo's independence the Kosovo's authorities took the overall governance of public institutions. As such in June 2008, the UN SecretaryGeneral announced the reconfiguration of the structure and profile of the international civil presence in Kosovo. As such, the European Union Rule of Law Mission in Kosovo (EULEX) was to "assume responsibilities in the areas of policing, justice and customs, under the overall authority of the U nited N ations, headed by [. . .] [the Special Representative of the Secretary-General], and in accordance with resolution 1244 (1999)" (European Union Rule of Law Mission EULEX). The relationship between UNMIK and EULEX has been notable with regard to the issue of the transfer of power and files from UNMIK to EULEX in the field of the rule of law. This process of transfer from UNMIK to EULEX took place on the initial operational day of EULEX 9 December 2008.According to the EULEX report delivered to the UN on 17 June 2009, the handover of case files from UNMIK to EULEX was successfully completed (EULEX report to the UN 2009). Moreover, this report indicated that EULEX conducted initial investigations for some of the priority cases (files) transferred from UNMIK. It is to be noted here that Kosovo judicial system since its establishment by UNMIK has been characterised by its unique hybrid nature. While under UNMIK administration Kosovo courts operated under UN SC Resolution 1244 and comprised international and local judges (Cerone and Baldwin 2004). After the declaration of independence UNMIK courts have been dissolved and replaced by Kosovo courts supplemented by EU mandated judicial presence the EULEX. The UNMIK war crimes jurisdiction has been transferred to EULEX judges and prosecutors. According to Bernard Borchard, the EULEX Head of Mission, EULEX inherited 1200 war crimes cases from UNMIK. From 12000 war crime cases 500 cases are closed or dismissed (due to lack of evidence). There are 300 cases pending with Kosovo and EULEX prosecutors within SPRK. There are 300 cases pending with The War Crimes Investigative Unit of KP and EULEX. More than 800,000 pages 
have been reviewed related to these cases. 51 new war crimes cases have been initiated, including the first-ever investigations into cases where acts of sexual violence or rape have been assessed as war crimes. Kosovo and EULEX prosecutors are currently investigating 100 war-crimes cases and there are 5 ongoing war-crimes trials. In total, and under the Kosovo legal framework, 15 war crimes cases have been adjudicated. Just under half of these (7) involved defendants of Serb ethnicity and just over half of these (8) involved defendants of Albanian ethnicity. There are additional 13 arrest warrants against Serbian defendants, but they are outside the Kosovo legal jurisdiction. There are 216 active cases on Missing Persons. Through field operations and forensic assessment, EULEX together with Kosovo experts are working that the remains of over 330 individuals are returned to their families (European Union External Action, EULEX and war Crimes, 2014). At the time of this writing EULEX is still in the process of handing over the cases to the local judiciary. It is expected that this process will be over before 2018 with the closure of the EULEX mandates (Council Decision (CFSP) 2016/947 2016).

Despite all the efforts, the success of EULEX is limited; in particular little progress has been reported in investigations and prosecutions which relate to the abductions of Serbs and other minorities (Amnesty International, 2012). EULEX did not demonstrate that the fight against impunity is one of its priorities, and it did not present a coherent strategy for fighting impunity (Amnesty International 2012). Several reasons have been mentioned by human rights NGOs (Amnesty International, 2012) and scholars (De Wet 2009, Rafaeli 2012, J.P. Jacque 2015) for affecting the EULEX's successes in combating impunity -lack of political will, insufficient resources allocated to handle cases, short term appointment of mission personnel without relevant experience, insufficient witness protection, that felt within the EULEX mandate, lack of cooperation with local stakeholders, lack of protection of local prosecutors and members of judiciary, weak domestic justice system, and allegations of corruption within the senior EULEX staff (The Guardian 2014). Lately, it is interesting to evidence that the Kosovo citizens have started to initiate cases against EULEX in front of the Human Rights Panel alleging violation of their rights as a consequence of the conflict and its aftermath. The Case no. 2014-34, Rejhane Sadiku-Syla against EULEX exemplifies 
this development. The complainant in this case, is related to the disappearance of the father of the complainant, who disappeared from his residence in northern Mitrovica in the course of an attack by a group of armed persons, believed to be of Serb ethnicity on 7 December 2000. The complainant submitted that EULEX Kosovo had violated her rights as guaranteed by Articles 2 and 3 of the European Convention (Council of Europe European Convention 1950) under their procedural limb. In particular, it was submitted that EULEX Prosecutors failed to initiate an investigation in accordance with Kosovo law and the mandate of EULEX Kosovo, that EULEX unduly delayed the investigative process and that in the referral of the case to Kosovo prosecutors, had neglected the seriousness of the case, the geographical location of the crime, (northern Mitrovica), the war crime character of the case and the fact that the incident had most likely been motivated by ethnic hatred. Having regard to the circumstances of the case in their entirety, the Panel found that the investigative efforts of EULEX Kosovo, in respect of the disappearance of the father of the complainant, were inadequate. These investigative shortcomings thereby resulted in violations of the rights of the complainant as guaranteed by Articles 2 and 3 of the European Convention in respect of the right to life and the prohibition of torture in their procedural limb, and those rights protected by Article 13, the right to an effective remedy, in conjunction with Article 2 of the European Convention. Given these findings, the Panel considered that it was unnecessary to further review the case under Article 8 of the European Convention. Indeed this case and others to come will further contribute to the development of the standards for protection of human rights of individuals under international peace building missions.

Generally "institutions of the international community have perceived criminal prosecution as the most forceful tool in transitional justice in Kosovo" (Philippe Kirshc Institute 2017). The EUs involvement in the establishment of the Special Court for Kosovo supports further this perception. The Special Rapportueer for the Parliamentary Assembly of the Council of Europe, Marty submitted a report entitled 'Inhuman treatment of people and illicit trafficking in human organs in Kosovo', on 12 December 2010 to the Committee on Legal Affairs and Human Rights (Committee on Legal Affairs and Human Rights 2010). The report was attached to a resolution by the Parliamentary Assembly of the Council of Europe 
calling on the EU to allocate resources through EULEX to investigate the allegations and protect witnesses (Assemblée Parlementaire Du Conseil De L'Europe Resolution 1782 2011). EULEX responded by establishing the Special Investigative Task Force, a special prosecutorial unit based in Brussels to pursue the investigation. Based on the first investigations, the EU and the US supported the idea of establishing a special court seated outside Kosovo and operating as an international court. The EU tied the court to Kosovo's European integration agenda and officially requested Kosovo to accept the establishment of a hybrid international court to investigate Dick Marty's allegations (Statement by Samuel Žbogar, Head of the EU Office in Kosovo and EU Special Representative 2014). On 24 April 2014, the Assembly of Kosovo ratified the exchange of letters between the Kosovo President Atifete Jahjaga and Baroness Ashton on the extension of the EULEX mandate. It also provided for reallocation of the sensitive judicial cases arising out of the investigation led by the Special Investigative Task Force to address the allegations of the 2011 Council of Europe Parliamentary Assembly report of the Special Rapporteur Dick Marty. Amendments to key legislation, including the Constitution, were adopted by the legislature to establish the Special Court and its prosecution office (BBC News, Kosovo parliament approves special war crimes court 2015). The Special Court comprising of the Special Chamber and Prosecutors Office will be part of the Kosovo judicial system and will be composed of international judges and prosecutors; it will operate both in Kosovo and at The Hague, in the Netherlands. The witnesses and the accused will be sent to The Hague to avoid witness intimidation and ensure a credible judicial process. The EU both drafted and sponsored the law on the establishment of the Special Court for Kosovo (Law No.05/L-053 On Specialist Chambers and Specialist Prosecutor's Office 2015) has been adopted on 3 august 2015. The Special Court will be a parallel system of courts composed of four judicial instances (three regular plus the constitutional one) external to the current judicial system of the Republic of Kosovo (Law No.05/L-053 On Specialist Chambers and Specialist Prosecutor's office 2015, Article 3). The Special Court will be composed of international judges and prosecutors appointed and financed by the EU, seated and operating in an EU member state (Law No.05/L-053 On Specialist Chambers and Specialist 
prosecutor's Office 2015, Article 27). After passing the constitutional amendment and the Law on Specialist Chambers, the EU is in the process of establishment and operationalisation of the Special court. The Netherlands has concluded with Kosovo an international agreement to host the seat of the Special Court, and the EU has already accorded financial support for it (an estimated $€ 300$ million) and has begun its staffing (Balkan Transitional Justice, 2016). The rules of procedure have been adopted however at the time of this writing no indictment is in place. Establishment of Special Court has caused controversy and hostility within the Kosovo society. The courts establishment is not supported by large part of the Albanian community because they consider it to be biased and unfair (Justice in Conflict 2017). Nevertheless, it is expected that establishment and the operationalization of the Special Court will have an imminent relevance for transitional justice processes and with it contribute to the Kosovo's EU integrative intentions.

\section{TRANSITIONAL JUSTICE IN KOSOVO AND THE EU ACCESSION}

In Copenhagen in 1993 the European Council established in its meeting the conditions for EU membership, which included "stability of institutions guaranteeing democracy, the rule of law, human rights and respect for and the protection of minorities" and provided financial assistance for countries in the region to strengthen democratic institutions and the rule of law as a way to "advance regional cooperation as well as reconciliation" (Council Regulation (EC) No 1085/2006 2006). Cooperation with the ICTY became a condition for membership candidacy, as spelled out in the Thessaloniki Agenda for the Western Balkans: "The EU urges all concerned countries and parties to co-operate fully with the International Criminal Tribunal for the former Yugoslavia. Recalling that respect for international law is an essential element of the SAP [Stabilisation and Association Process], the EU reiterates that full co-operation with ICTY, in particular with regard to the transfer to The $\mathrm{H}$ ague of all indictees and full access to documents and witnesses, is vital for further movement towards the EU" (General Affairs \& External Relations 
Council 2003). Concerning Kosovo since 2002 there has been an intensification of the EU-Kosovo cooperation, marked with a number of important developments leading to practical effect to Kosovo's 'EU perspective'. In October 2012 the European Commission initiated the feasibility study for a Stabilisation and Association Agreement (SAA) between the EU and Kosovo (European Commission (2012a). The contents of the Commission's report were broadly endorsed by the Council in December (Council of the European Union 2012). Kosovo was subsequently judged, in a joint report issued in April 2013 by the Commission and the High Representative of the Union for Foreign Affairs and Security Policy, to have met the benchmarks (European Commission and High Representative of the European Union for Foreign Affairs and Security Policy 2013a). On 19 April 2013, after months of very difficult and protracted EUmediated talks, including ten rounds at Heads of Government and EU High Representative level, a modality - based on an outline, fifteen points deal - was reached between the two sides (First Agreement of Principles Governing the Normalization of Relations 2013). On 22 April the Commission issued recommendations to the Council that negotiations should be opened on a SAA between the EU and Kosovo (European Commission 2013). The Council welcomed the recommendations but it left the final acceptance decisions to be taken by the European Council at its meeting in June 2013. The signing of Stabilization and Association Agreement (SAA) took place on 22 October 2015 establishing the contractual relationship between EU and Kosovo authorities which entails mutual rights and obligations and covers a wide variety of sectors. With the signing of the SAA the EU made transitional justice part of the Kosovo accession demands. In December 2015, the Government of Kosovo approved its National Action Plan for the Implementation of the Stabilization and Association Agreement (NAPISAA). The General Principles of the SAA, included within the NAPISAA oblige Kosovo Government to approve a National Transitional Justice Strategy which will define the modality for dealing with the past and reconciliation in Kosovo. Despite the fact that the Inter-ministerial Working Group for Dealing with the past and Reconciliation has been established back in 2012(Decision No.03/77, 04.06.2012. updated and amended with the Decisions No. 06/181, dated 02.04.2014 and No.04/200 dated 15.10.2014) still there is no 
document in a form of a national strategy in place. It has been stated that the work of the IMWG in the process of drafting the strategy "was hampered by deficiencies related to leadership and management, political ownership, representation and participation of Kosovo's minority communities, and engagement of the public, among others(A hmetaj and U nger 2017). The IM W G activities are not present in public, and it is hard to learn if IMWG is functional or not. Considering the mentioned shortcomings, there is a high risk that the IM W G will fail to develop a N ational Strategy that has the credibility and legitimacy to advance societal transformation" (Ahmetaj and Unger 2017).

On the other hand the EU facilitated dialogue for normalisation of relations between Prishtina and Belgrade has been initiated back on 8 March 2011. Since then, a considerable number of technical agreements regulating the cadastre, civil registry books, customs stamp, recognition of the university diplomas, freedom of movement, regional representation, integrated boundary management (IBM), official visits and liaison officers, collection of customs duties, development fund for the Northern Kosovo, vehicle insurance, free trade, the "Peace Park" in Mitrovica, civil protection and the dialogue of Chambers of Commerce have been reached between Kosovo and Serbian authorities including the latest agreement on judiciary on October 2017 (European Union External Action, Dialogue between Belgrade and Pristina 2017). However to date the issue of dealing with the past and the transitional justice process have not been discussed in the Prishtina -Belgrade dialogue despite the fact that CSOs and associations of the victims' families have requested the Kosovo authorities bring these issues in to the discussion table. The "political elites in Kosovo and Serbia still perceive the Transitional Justice process "as harmful to their respective national interest, humiliating for the ethno-nationalist factions, and consequently, Transitional Justice mechanisms were implemented through international, domestic and hybrid trials" (Morreale 2015). The lack of cooperation with Serbia in prosecuting war crimes remains the biggest challenge for bringing justice for war crimes (Kosovo 2.0 2017). All this elements are hampering the initiation of the overall and meaningful transitional justice processes that would lead to sustainable peace and reconciliation. 
While under UNMIK administration, $\mathrm{n}$ order to address the very painful part of the past that of missing persons from all parties affected by the conflict irrespective of their ethnic background, the Assembly of Kosovo has established the Commission on Human Rights, Gender Balance, Missing Persons and Petitions mandated to address the issue of missing persons. The Commission has been vocal in calling for responsibility from the Kosovo Government; they have not however developed any strategies or initiated any specific measures. The successful resolution regarding the fate of missing persons is conditioned by the success of prosecution and trials of war crimes, and Serbia's stance on the past which is evidenced in the Prishtina -Belgrade dialogue. Back in 2004, during the internationally mediated dialogue between Prishtina and Belgrade on technical issues, both governments agreed on the establishment of a Working Group on Missing Persons which held its first meeting in March 2005 (ICRC Press Release 2005). The government representatives of both parties were mediated by the International Committee of the Red Cross (ICRC) and the Kosovo delegation was accompanied by UNMIK. Although both governments verbally accepted the responsibility to keep the working group going, no real progress was made regarding sharing sensitive information doe to political reasons. The political changes after Kosovo's declaration of independence, have delayed the progress of the Working Group, and with it the disclosure of the fate of the missing persons. The slow progress and the agony related to the lack of resolution of the fate of the missing persons, abstention and not appropriately dealing with the war crimes cases affects also the process of returns which remains critical for the minority communities in Kosovo. After the adoption of the Constitution, a Consultative Council for Communities (CCC) has been established under the auspices of the President of Kosovo (Law No. 03/L-047). The CCC has the mandate to act as a liaison mechanism between the communities and the government. The CCC is now a constitutionally-mandated institution, comprising community representatives from both civil society and political parties, and key government officials. A similar mandate applies also to the Office for Communities established within the Office of the Prime Minister. The Office for Communities has been established to act as a promoter of communities' rights which will receive vast attention from the government. The 
other institutional framework of minority consultative bodies consists of the Committee on Rights and Interests of Communities, based in the Kosovo Assembly, and Commissioner for usage of languages within the Prime Minister Office. These minority consultative bodies have been initiated by the international community, and their establishment and functioning is seen as an appropriate for ensuring that constitutional commitments on minority rights are effectively implemented through direct engagement with minority representatives in consultative, decision-making and coordination processes (Visoka \& Beha 2011). Related to the status of civilian victim's while the Kosovo Assembly adopted the 'Law on Status and Rights of the families of Martyrs, KLA War Invalids and Veterans, and the Families of Civilian Victims of War' (Law No. 04/L-054 2011).The Law covers the following victim groups: Veterans of KLA and their families, Invalids of KLA, War hostages o Missing KLA soldiers, Civilian victims, Civilian hostages, Civilian missing persons (Law No. 04/L-054 2011, Article 2).The benefits comprise cash-based compensation and non-cash based compensation. In regard to the conflict related crimes of sexual violence the former President of Kosovo, Mrs. Atifete Jahjaga, has decreed the establishment of the National Council for the Survivors of Sexual Violence during the War on March 5, 2014. In accordance with the Constitution and laws of the Kosovo, the Council aims to coordinate the work and activities of institutions and the civil society, based on their scope, for the treatment of survivors of sexual violence during the war. Under her sponsorship the Regulations of procedure for the National Council for Survivors of Sexual Violence during the War has been drafted, the National Council for the Survivors of Sexual Violence has been established and the budget for the victims has been allocated. The Civil Society's activities on transitional justice are related to collection of data's and their documentation, few organizations working for interethnic dialogue, and some supporting truth -finding grassroots initiative to establish a regional truth commission in the former Yugoslavia known as RECOM. Despite all these initiatives the overall consultation processes involving all communities in Kosovo has not taken place du to the fact that there are different perceptions on the conflict and the narrative of the past by the 
communities on the conflict itself and the role of international community in Kosovo.

On February 2017 the President of Kosovo, Hashim Thaci, has announced plans to establish a truth and reconciliation commission to help reconcile Kosovo's ethnic-Albanian majority and Serb minority. According to President Thaci the truth commission will not replace the dialogue between Kosovo and Serbia, but it will be a facilitator in improving of relations between the two countries (Reuters 2017). Since February 2017, several consultative meetings under the leadership of the Office of the President have taken place where representatives of all communities, religious leaders and representatives of CSOs have taken part. During these consultative meetings it was expressed the will to undertake the overall and all-inclusive consultation process in order to best decide the way forward in bridging the existing gap between the communities. It is expected that the Truth Commission for Kosovo will be established by the end of 2017 . While president Thaci claims that "the aim of this commission will be the truth as the way to heal society from revenge and hatred," (Balkan Transitional Justice, Kosovo 'Trapped by the Past', Thaci 2017) analysts have questioned what the proposed Truth and Reconciliation Commission can achieve in practical terms in Kosovo's deeply divided society and also have questioned its timing. If the Truth and Reconciliation Commission is established "as part of some political bargaining between him (the President) and the international community under the pretext of stability and peace, then the Truth Commission is doomed to fail" (Ahmetaj 2017). However, at this stage it remains to be seen if this initiative is a genuine one or establishment of this commission is only for the political calculations and for satisfying the EU conditionality.

\section{CONCLUSIONS}

From the analyses of the constitutive documents establishing the international organizations, policies undertaken, development of tools and guidance for supporting transitional justice processes it is evident that the UN and EU have placed transitional justice processes as crucial element wards achieving peace 
and international justice. Though specifically not mentioned in their constitutive documents international organizations like the UN and EU have integrated the concept and initiatives in policy documents and strategies, and above all, in their peace building missions. The EU establishes the framework of Transitional Justice through a variety of sources and legal texts. However, the majority of references to Transitional Justice are found in declarations, reports and consensus documents. However, adopting transitional justice as an EU approach in all post conflict situations could help it achieve these commitments. Transitional justice is not a new policy area for the EU member states. The experience that some of them EU member states have could serve as a leading practice in establishing such an approach. In the case of Kosovo it seems unlikely that the EU support after its declaration of independence, will go beyond support for the work carried out by the International Tribunal for the former Yugoslavia, the work of EULEX judges in the mix tribunals in Kosovo and the activities of the Special court for Kosovo. Up to now EU through EULEX was partially involved in transitional justice processes through the retributive measures, placing intenrationla judges in hybrid courts, initiation and prosecution of war crime cases, and capcity building of teh local judges in handlin the war crime cases. The work of international judges, first of the UNMIK and latter of EULEX is to be respected despite the criticism. However, only instituting retributive measures are not enough in dealing with the past violations and bridging the existing interethnic divide in Kosovo. The above analysis moreover indicate that although the EU did acknowledge restorative justice as a legitimate part of transitional justice, in Kosovo it did not attest to true recognition of the urgent need for restorative transitional justice mechanisms. Considering that the current dialogue between Prishtina and Belgrade is concentrated only on solving the technical matters and the division that exist between the two communities formerly in conflict it is unlikely that the restorative mechanism will be initiated through the dialogue. Therefore, the international presence especially EU should adopt a strategy that would encompass a restorative approaches to transitional Justice - that will lead to reconciliation of communities. supporting the activities that will contribute to interethnic dialogue, developing activities with social, economic and educative 
characters that will bring together communities, working with different groups within the communities like women and youth are among the few modalities that could have laid the grounds for communication and with it support the cooliving. Above all a proactive involvement of local population and community representatives in the activities and decision making by the international presences could have provided international presences with insights on the needs of the communities. Only insisting on purely judicial measures in postconflict situations may have the opposite effect to what is desired and may prevent the realization of peace and stability. However, the EU in Kosovo will have an important part to play in the future supervision of the process of SAA, a situation which indeed will lead to the implementation of the Transitional Justice strategies to help lay the foundation for reconciliation between the Albanian majority and the Serb minority. Rather than remaining simply a supporter of transitional justice endeavours undertaken by others, the EU should also draw on its experience at home and abroad, and on lessons learnt from other actors such as the UN, to develop a strategic approach to transitional justice as a way of achieving its foreign policy objectives. This could help close the credibility gap between declared commitments to peace, human rights and international law and their realization.

\section{REFERENCES}

- $\quad$ Ahmetaj N., and Unger Th., Kosovo's Framework for Dealing With the Past at a Turning Point: Civil society review of progress towards a National Strategy on Transitional Justice accessed 3 November, 2017: file:/ / / C:/Users/IBCM-AC002/Downloads/civil-society-review-report-finaleng.pdf .

- $\quad$ Amnesty International, 2000. Federal Republic of Yugoslavia (Kosovo): setting the standard? UNMIK and KFOR's response to the violence in M itrovica. Accessed 23August 2017: https://www.amnesty.org/download/Documents/140000/eur700132000en.pd. - Amnesty International, 2004a. Kosovo and Bosnia-Herzegovina: the apparent lack of accountability of international peace-keeping forces in Kosovo 
and Bosnia-Herzegovin, 21 March 2004. • Accessed 25 June 2017: https://www.amnesty.org/en/documents/eur05/ 002/2004/en/.

- $\quad$ Amnesty International, 2004b. Serbia and M ontenegro (Kosovo/Kosova): The M arch violence: KFOR and UNMIK's failure to protect the right of the minority communities. Accessed 5 July 2017: https://www.amnesty.org/en/search/..Amnesty International. 2012 Kosovo: Time for EULEX to prioritize war crimes. Accessed 12 September 2017: http://www.amnesty.eu/content/assets/260412_EULEX_Report.pdf.

- Assemblée Parlementaire Du Conseil De l'Europe Resolution 1782 (2011)1 Final version Investigation of allegations of inhuman treatment of people and illicit trafficking in human organs in Kosovo. Accessed on 3 November 2017: http:/ / semanticpace.net/tools/pdf.aspx?doc=aHR0cDovL2Fzc2VtYmx5LmNvZS5pbnQvbncve G1sL1hSZWYvWDJILURXLWV4dHIuYXNwP2ZpbGVpZD0xNzk0MiZsYW5nP UVO\&xsl=aHR0cDovL3NlbWFudGljcGFjZS5uZXQvWHNsdC9QZGYvWFJlZi1 XRC1BVC1YTUwyUERGLnhzbA==\&xsltparams=ZmlsZWlkPTE3OTQy\#x0026;1 ang=en .

- $\quad$ Balkan Transitional Justice, 'Kosovo's New War Court: Major Challenges Ahead', Accessed on

November,2017:http:/ / www.balkaninsight.com/en/article/kosovo-s-new-warcourt-major-challenges-ahead-08-11-2015 .

- $\quad$ BC News, Kosovo parliament approves special war crimes court 4 August 2015. Accessed 3 noveber 2017: http://www.bbc.com/news/worldeurope-33770897 . Borchardt B., EULEX Head of Mission EULEX and War Crimes. Accessed 20 September, 2017: http://www.eulexosovo.eu/en/news/000427.php.

- Balkan Insight, Balkan Transitional Justice, Kosovo 'Trapped by the Past': Thaci, 01 2017. Accessed 3 November 2017: https:/ / www.balkaninsight.com/en/article/kosovo-trapped-by-the-past-thaci-03-012017.

- $\quad$ Bernhardt D. and Ferizi, A. 2011. The ICO and Dealing with the Past in Kosovo: Interview with Nora Raefeille," Made in Kosovo 6 (2011).

- $\quad$ Cerone, J. \& Baldwin, C. (2004). Explaining and Evaluating the UNMIK Court System. Internationalized Criminal Courts: Sierra Leone, East Timor, Kosovo, and Cambodia Eds by C.P.R. Romano: Oxford University Press.

Council of Europe, European Convention for the Protection of Human Rights and Fundamental Freedoms, as amended by Protocols N os. 11 and 14, 4 November 
1950, ETS

5.

Accessed 8

October

2017::

http://www.refworld.org/docid/3ae6b3b04.html ;

- $\quad$ Constitution of Republic of Kosovo, 2008. Accessed 12 September, 2017 : http://www.kryeministri-ks.net/repository/docs/Constitution1Kosovo.pdf

- Comprehensive Proposal for the Kosovo Status Settlement. 2007. Accessed 10

October,

2017:

https://www.kuvendikosoves.org/common/docs/Comprehensive\%20Proposal $\% 20$.pdf . 975/1999).

Council Regulation (EC) 975/1999 OJ L120/1, 1999, Art 2. (Regulation - $\quad$ Council Regulation (EC) No 1085/2006of 17 July 2006 establishing an Instrument for Pre-Accession Assistance (IPA)

- Council of the European Union (2012), Council Conclusions on Enlargement and Stabilisation and Association Process, General Affairs Council meeting, Brussels. Accessed 11 September, 2017: http://www.consilium.europa.eu/uedocs/cms_data/docs/pressdata/EN/gena ff/134235.pdf . Committee on Legal Affairs and Human Rights, Inhuman treatment of people and illicit trafficking in human organs in Kosovo*1 Report Rapporteur: Mr Dick Marty, Switzerland, Alliance of Liberals and Democrats for Europe. Accessed on 3 November, 2017: http://www.assembly.coe.int/CommitteeDocs/2010/ajdoc462010prov.pdf .

- $\quad$ Davlis L., The European Union and Transitional Justice. This paper was prepared in the framework of the Civil Society Dialogue Network (CSD N), 3 April 2014 in Brussels. Acessed on 3 November 2017: http://eplo.org/wpcontent/uploads/2017/02/EPLO_CSDN_Background-Paper_EU-and-

Transitional-Justice.pdf .

- $\quad$ Di Lellio A. and MeCum C. 2012. Engineering Grassroots Transitional Justice in the Balkans: The Case of Kosovo East European Politics and Societies. East European Politics and Societies. Accessed 10 September, 2017: http://www.annadilellio.com/wp-content/uploads/2013/08/TJKosovo.pdf .

- $\quad$ De Wet E. The Governance of Kosovo: Security Council Resolution 1244 and the Establishment and Functioning of EULEX. The American Journal of International Law, Vol. 103, No. 1 (Jan., 2009), pp. 83-96.Decision No.03/77, 04.06.2012. updated and amended with the Decisions No. 06/181, dated 02.04.2014 and No.04/200 dated 15.10.2014. Accessed on 3 November, 2017: http://www.kryeministri-

ks.net/repository/docs/RREGULLORE_QRK_Nr_18_2014_PER_PUNEN_E 
_GRUPIT_PUNUES_PER_BALLAFAQIM_ME_TE_KALUAREN_DHE_PAJTIM. pdf .

- $\quad$ European Union Rule of Law Mission (EULEX). Accessed 12 September, 2017: http:/ / www.eulex-kosovo.eu/en/info/whatisEulex.php .

- $\quad$ European Commission and High Representative of the European Union for Foreign Affairs and Security Policy (2013a) Joint Report to the European Parliament and the Council on Kosovo's Progress in Addressing Issues Set Out in the Council Conclusions of December 2012 in View of a Possible Decision on the Opening of Negotiations on the Stabilisation and Association Agreement, Brussels, 22 April, JOIN (2013). Accessed 10 October, 2017: http:/ / ec.europa.eu/enlargement/pdf/key_documents/2013/ks_spring_report _2013_en.pdf.

- European Union, Treaty on European Union (Consolidated Version), Treaty of Maastricht, 7 February 1992, Official Journal of the European Communities C 325/5; 24 December 2002. Accessed 11 September 2017: http:/ / www.refworld.org/docid/3ae6b39218.html .

- $\quad$ European Commission, “The Multiannual Financial Framework: The External Action Financing Instruments", MEMO/13/1134.

- $\quad$ European Security Strategy approved at the European Council meeting held in Brussels on the 12th of December 2003. Accessed 10 October 2017: https://www.consilium.europa.eu/uedocs/cmsUpload/78367.pdf .

- $\quad$ European Union: The EU's Policy Framework on support to transitional justice. $\quad$ Accessed $10 \quad$ October2017: http:/ / eeas.europa.eu/top_stories/pdf/the_eus_policy_framework_on_support _to_transitional_justice.pdf.

- $\quad$ European Union, Treaty Establishing the European Community (Consolidated Version), Rome Treaty, 25 March $1957 . \quad$ Accessed: http:/ / www.refworld.org/ docid/3ae6b39c0.html.

- $\quad$ EU Guidelines to EU Policy Towards Third Countries on Torture and Other Cruel, Inhuman or Degrading Treatment or Punishment. Accessed 10 October 2017: http:/ / www.consilium.europa.eu/uedocs/cmsUpload/TortureGuidelines.pdf . - $\quad$ European Commission (2012a) Communication From the Commission to the European Parliament and the Council on a Feasibility Study for a Stabilisation and Association Agreement Between the European Union and Kosovo, Brussels, 10 October, Com (2012) 602 final. Accessed on 18 September 2017: 
http:/ / ec.europa.eu/enlargement/pdf/key_documents/2012/package/ks_feasi bility_2012_en.pdf.

- $\quad$ European Commission (2013) Recommendation for a Council Decision Authorising the Opening of Negotiations on a Stabilisation and Association Agreement Between the European Union and Kosovo, Brussels, 22 April, COM (2013) $200 \quad$ final, $\quad$ Accessed 2 September 2017: http:/ / ec.europa.eu/enlargement/pdf/key_documents/2013/ks_recommendati on_2013_en.pdf .

- European Union External Action, EULEX and War Crimes. Bernd Borchardt, EULEX Head of Mission. Accessed 3 November 2017: http:/ / www.eulex-kosovo.eu/en/news/000427.php

- $\quad$ European Union External Action, Dialogue between Belgrade and Pristina, 2017. Accessed on 3 November 2017: https:/ / eeas.europa.eu/topics/eufacilitated-dialogue-belgrade-pristina-relations_en .

- $\quad$ EULEX report to the UN, 17 June 2009,.Acessed 3 November 2017: http://www.eulex-kosovo.eu/en/pressreleases/0049.php .

- $\quad$ First Agreement of Principles Governing the Normalisation of Relations. Accessed $12 \quad$ September 2017: http://www.kryeministriks.net/repository/docs/FIRST_AGREEMENT_OF_PRINCIPLES_GOVERNING _THE_NORMALIZATION_OF_RELATIONS,_APRIL_19,_2013_BRUSSELS_en.p df.

- file:///C:/Users/PC/Downloads/TJ_Guidance_Note_March_2010FIN AL\%20(1).pdf.

- Hayner Priscilla 1994 "Fifteen truth commissions, 1974 to 1994: a comparative study." Human Rights Quarterly 16: 597-655

- $\quad$ Hayner, Priscilla (2001) Unspeakable truths. New York: Routledge.

- Human Rights Watch, 2004. Failure to protect anti-minority violence in Kosovo, March 2004. Accessed 5 July 2017: https:/ / www.hrw.org/report/2004/07/25/failure-protect/anti-minorityviolence-kosovo-march-2004.General Affairs \& External Relations Council (GAERC). Extracts from successive General Affairs \& External Relations Councils 16 June 2003. Accessed 10 October 2017: http:/ / www.consilium.europa.eu/ueDocs/cms_Data/docs/pressdata/en/gena /76201.pdf .

- $\quad$ ICRC Press Release, Kosovo: First meeting of working group on missing persons 11-03-2004 News Release. Accessed 12 September 2017: 
https://reliefweb.int/report/serbia/kosovo-meeting-working-group-missingpersons.

- Institute for Democracy and Conflict Resolution: Briefing Paper Transitional Justice 2011.

- International Crisis Group, 2004. Collapse in Kosovo. Europe Report No. 155, 22 April, 2004. Accessed on 5 July 2017: https://www.files.ethz.ch/isn/28082/155_collapse_in_kosovo_revised.pdf.

- Jacque, J.P. (2015). Review of the EULEX Kosovo Mission's Implementation of the Mandate with a Particular Focus on the Handling of Recent Allegations. Accessed on 13 September 2017: eeas.europa.eu/statementseeas/docs/150331-jacque-report-en.pdf> .

- Justice in Conflict, "It is a good thing that we don't know." - An Interview with Bekim Blakaj on the Travails of Transitional Justice in Kosovo, 11 September 2017. Accessed on 3 November 2017: https://justiceinconflict.org/2017/09/11/it-is-a-good-thing-that-we-dont-knowan-interview-with-bekim-blakaj-on-the-travails-of-transitional-justice-inkosovo/.

- Kosovo 2.0 Nora Ahmetaj, Kosovo President must be Careful when establishing the Truth and Reconciliation Commission, 28, 02, 2017. Accessed on 3 November 2017: http://kosovotwopointzero.com/en/president-must-carefulestablishing-truth-reconciliation-commission/.

- Kosovo 2.0, Drita Hajdari. Without Cooperation with Serbia it is Impossible to Bring Justice for War Crimes, by Leonora Aliu, 13.04.2017. Accessed 3 November 2017: http://kosovotwopointzero.com/en/drita-hajdariwithout-cooperation-serbia-impossible-bring-justice-war-crimes/ .

- Law No. 04/L-054 On the Status and the Rights of the Martyrs, Invalids, Veterans, Members of Kosova Liberation Army, Civilian Victims of War and Their Families. Accessed on 3 November 2017: http://www.kuvendikosoves.org/common/docs/ligjet/Law\%20on\%20the\%20s tatus $\% 20$ of $\% 20$ the $\% 20$ martyrs\%20of\%20war.pdf.

- Law on the Protection and Promotion of the Rights of Communities and their Members in Kosovo Law no 03/1 -04712. Accessed 1 September 2017: http://www.gazetazyrtare.com/egov $/$ index.php?option=com_content\&task=view\&id=148\&Itemid=56\&lang=en.

- Law ON SPECIALIST CHAMBERS AND SPECIALIST PROSECUTOR'S OFFICE, Law No.05/L-053. Accessed on 3 November 2017: https://www.kuvendikosoves.org/common/docs/ligjet/05-L-053\%20a.pdf . 
- Military-Technical Agreement, signed between KFOR and Yugoslav Serbian Forces on June 9, 1999. Accessed on 13 September 2017: http://www.nato.int/kosovo/docu/a990609a.htm .

- Morreale V., Dealing with the past for a peace-built future Kosovo, 15 September 2016. Accessed on 3 November 2017: http://www.ks.undp.org/content/kosovo/en/home/presscenter/articl es/2016/09/15/dealing-with-the-past-for-a-peace-built-future-kosovo/ .

- Muižnieks N. 2012. Why does justice matter for reconciliation? Address on behalf of the Council of Europe Commissioner for Human Rights. Presentation in the conference Dealing with the Past and Reconciliation - What kind of truth seeking mechanism does Kosovo need?" International Civilian Office, Pristina, 22 May 2012. Accessed on 13 September 2017: https:// wcd.coe.int/com.instranet.InstraServlet?command=com.instranet.CmdB lobGet\&InstranetImage $=2109289 \&$ SecMode $=1 \&$ DocId $=1902992 \&$ Usage $=2$.

- $\quad$ Official Journal of the European Union, L115/50-56, 28 of April 2006. Accessed on 11 October 2017: http:// eur-lex.europa.eu/oj/direct-access.html - Official Journal of the European Union COUNCIL DECISION (CFSP) 2016/947 of 14 June 2016.Accessed on3 November 2017: http://www.eulexkosovo.eu/eul/repository/docs/COUNCIL\%20DECISION\%20CFSP\%202016947 .pdf .

- $\quad$ Philippe Kirshc Institute, Flexibility in Transitional Justice,31 July 2017. Accessed 3 November 2017: http://www.kirschinstitute.ca/flexibility-intransitional-justice/ .

- $\quad$ Rafaeli N. 2012.Challenges in Dealing with the Past in Kosovo: From Territorial Administration to Supervised Independence and Beyond, Politorbis Nr. $54-2 / 201 . \quad$ Accessed 10 October 207: http://www.pgaction.org/pdf/Politorbis_2_2012_No54_10th\%20anniversary\%2 0of $\% 20$ the $\% 20$ ICC.pdf .

- $\quad$ Regulation (EU) No 230/2014 of the European Parliament and of the Council of 11 March 2014 establishing an instrument contributing to stability and peace. Accessed 12 September 2017: http://ec.europa.eu/dgs/fpi/documents/140311_icsp_reg_230_2014_en.pdf .

- Report of the UN secretary General 2002. On the Rule of Law and Transitional Justice in Conflict and Post conflict Societies (S/2004/616).

- $\quad$ Reuters, Kosovo to form truth commission as wounds from 1998-99 war fester, World News, February 13, 2017. Accessed on 3 November 2017: 
http://www.reuters.com/article/uk-kosovo-president-commission/kosovo-toform-truth-commission-as-wounds-from-1998-99-war-fester-idUKKBN15S1U5 .

- $\quad$ Teitel G.R., Transitional Justice Genealogy, 16. Harvard Human Rights Journal Vo. 16 spring 2003, pp 69-94.

- United Nations Office of the United Nations High Commissioner for Human Right 2006. Rule-of law Tools for Post-conflict States Vetting: an operational framework. Accessed 10 September 2017: http://www.ohchr.org/Documents/Publications/RuleoflawVettingen.pdf .

- United Nations Secretary-General, The rule of law and transitional justice in conflict and post conflict societies (2004) UN Doc. S/2004/616.

- $\quad$ United Nations, Charter of the United Nations, 24 October 1945, 1 UNTS XVI. Accessed 8 October 2017: http://www.refworld.org/docid/3ae6b3930.html - UN General Assembly, International Covenant on Civil and Political Rights, 16 December 1966, United Nations, Treaty Series, vol. 999, accessed 8 October 2017:

- $\quad$ United Nations Guidance Note of the Secretary General United Nations Approach to Transitional Justice accessed 13 September 2017: http://www.refworld.org/docid/3ae6b3aa0.html .

- UN General Assembly, Convention Against Torture and Other Cruel, Inhuman or Degrading Treatment or Punishment, 10 December 1984, United Nations, Treaty Series, vol. 1465, p. 85.Accessed 8 October 2017: http://www.refworld.org/docid/3ae6b3a94.html.

- UN General Assembly, International Convention for the Protection of All Persons from Enforced Disappearance, 20 December 2006.Accessed 8 October 2017: http://www.refworld.org/docid/47fdfaeb0.html .

- UN General Assembly, Universal Declaration of Human Rights, 10 $\begin{array}{llllll}\text { December 1948, } 217 \quad \text { A } & \text { (III), accessed } 8 \text { October }\end{array}$ http://www.refworld.org/docid/3ae6b3712c.html .

- UN General Assembly, International Convention on the Elimination of All Forms of Racial Discrimination, 21 December 1965, United Nations, Treaty Series, vol. $\quad 660$. Accessed 8 October http://www.refworld.org/docid/3ae6b3940.html .

- UN General Assembly, Convention Against Torture and Other Cruel, Inhuman or Degrading Treatment or Punishment, 10 December 1984, United Nations, Treaty Series, vol. 1465. Accessed 8 October 2017: http://www.refworld.org/docid/3ae6b3a94.html. 
- UN General Assembly, International Convention for the Protection of All Persons from Enforced Disappearance, 20 December 2006. Accessed 8 October 2017: http://www.refworld.org/docid/47fdfaeb0.html.

- $\quad$ UN General Assembly, Convention on the Rights of the Child, 20 N ovember 1989, U nited Nations, Treaty Series, vol. 1577. Accessed 8 October 2017: http://www.refworld.org/docid/3ae6b38f0.html.

- UN General Assembly, Convention Against Torture and Other Cruel, Inhuman or Degrading Treatment or Punishment, 10 December 1984, United Nations, Treaty Series, vol. 1465, p. 85Accessed 8 October 2017: http://www.refworld.org/docid/3ae6b3a94.html .

- UN General Assembly, International Convention for the Protection of All Persons from Enforced Disappearance, 20 December 2006. Accessed 8 October 2017: http://www.refworld.org/docid/47fdfaeb0.html .

- United Nations Security Council Resolution 1244, 1999 U.N. Doc. S/RES/1244 (June 10, 1999).

- UNM IK (2008a) Report of the Secretary General on the United Nations Interim Administration Mission in Kosovo (UNMIK), 12 June, 2008. Accessed 2 September 2017:http://www.unmikonline.org/UNMIKONLINE 2009/misc/docs/sc-reports/S-2008-354.pdf .

- $\quad$ United Nations Security Council, The Rule of law and transitional justice in conflict and post-conflict societies, S/2004/616.

- UNMIK/REG/2000/66 21 December 2000 Regulation no. 2000/66 on benefits for war invalids of Kosovo and for the next of kin of those who died as a result of the armed conflict in Kosovo. Accessed 4 September 2017: http://www.unmikonline.org/regulations/2000/reg66-00.htm.

- Sission Jonathan: A Conceptual Framework for Dealing with the Past. 2010. Swisspeace. Accessed on 2 November 2017: http:// www.swisspeace.ch/fileadmin/user_upload/Media/Publications/DwP _Conceptual_Framework_October2012.pdf

- $\quad$ Statement by Samuel Žbogar, Head of the EU Office in Kosovo and EU Special Representative, 'The truth beyond any doubt (10/04/2014). 
- The Guardian, EU's biggest foreign mission in turmoil over corruption row. Accessed 12 September http://www.theguardian.com/world/2014/nov/05/eu-facing-questionsdismissal-prosecutor-alleged-corruption.

- $\quad$ Visoka G.and Beha A., Minority Consultative Bodies in Kosovo: A Quest for Effective Emancipation or Elusive Participation? Journal on Ethnopolitics and Minority Issues in Europe Vol. 10, No 1, 2011, pp.1-30.

- Ward, M., Gender, Citizenship and the Future of the Northern Ireland Peace Process, Eire-Ireland, 40: 3 \& 4, Fall/W in 2005. 